\title{
$9-2017$
}

\section{Critical Thinking in Religious Education}

Shayne Anderson

shayne_anderson@byu.edu

Follow this and additional works at: https://scholarsarchive.byu.edu/re

Part of the Mormon Studies Commons

\section{BYU ScholarsArchive Citation}

Anderson, Shayne. "Critical Thinking in Religious Education." Religious Educator: Perspectives on the Restored Gospel 18, no. 3 (2017): 69-81. https://scholarsarchive.byu.edu/re/vol18/iss3/6

This Article is brought to you for free and open access by the Journals at BYU ScholarsArchive. It has been accepted for inclusion in Religious Educator: Perspectives on the Restored Gospel by an authorized editor of BYU ScholarsArchive. For more information, please contact ellen_amatangelo@byu.edu. 


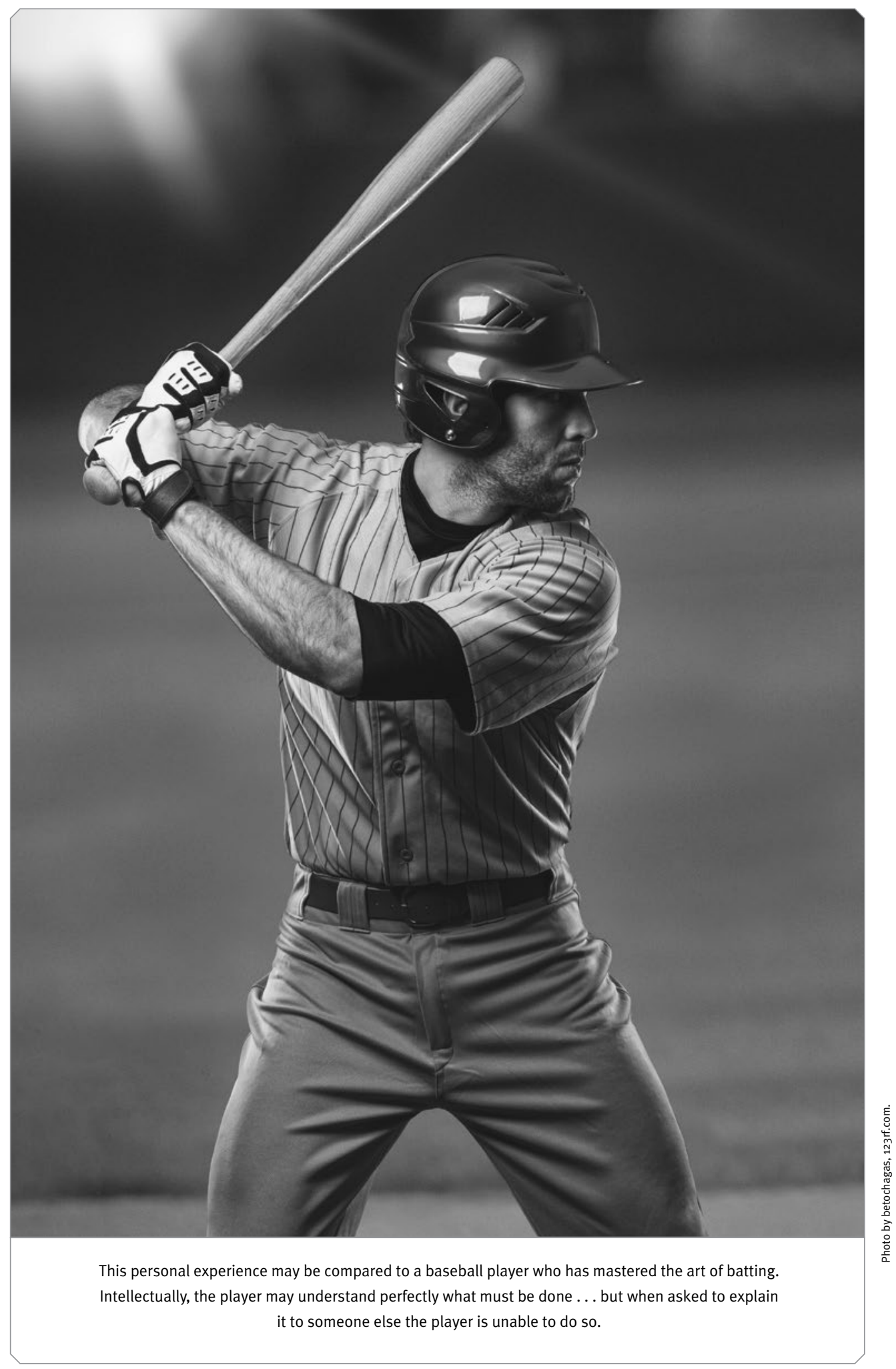

\section{Critical Thinking in Religious Education}

SHAYNE ANDERSON

Shayne Anderson (andersonsi@ldschurch.org) is an instructor at South Ogden Junior Seminary.

common argument in an increasingly secular world today is that religion 1 poses a threat to world peace and human well-being. Concerning the field of religious education, Andrew Davis, an honorary research fellow at Durham University, argues that religious adherents tend to treat others who do not agree with them with disrespect and hostility and states that efforts to persuade them to behave otherwise would be "profoundly difficult to

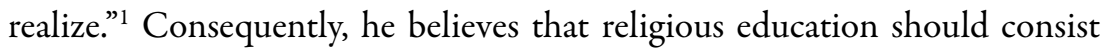
only of a moderate form of pluralism. Religious education classes, in his view, should not make claims of one religion having exclusive access to the truth.

Others argue that religious education should consist only of teaching about religion in order to promote more democratic ways of being. ${ }^{2}$ Their perception is that religion is yet another distinguishing and divisive tool used by those who seek to discriminate against others, thus impeding the progress of pluralistic democracies. Further, those perceived as religious zealots, so the argument goes, are the least apt to give critical thought to either their own beliefs or the beliefs of others. ${ }^{3}$ This reasoning, in which religion and critical 
thinking are viewed as antithetical, is especially prevalent in popular culture, outside the measured confines of peer-reviewed publishing.

Reasons for why religion and critical thinking might be viewed as incompatible are as varied as the authors who generate the theories. They include the following: religions often claim to contain some amount of absolute truth, an idea in itself that critical theorists oppose; individual religions generally do not teach alternate views, a requisite for critical thinking; and, in critical theory, truth is comprised of "premises all parties accept." ${ }^{\text {"T }}$ Theorist Oduntan Jawoniyi reduces the argument down to the fact that religious claims of truth "are empirically unverified, unverifiable, and unfalsifiable metaphysical truths."

One explanation for variations in opinions concerning the place of critical thinking in religious education may be that no consistent definition exists for critical thinking, a concept that stretches across several fields of study. For instance, the field of philosophy has its own nuanced definition of critical thinking, as does the field of psychology. My first aim in this article is to survey a range of definitions in order to settle upon a functional definition that will allow for faith while still fulfilling the objectives of critical thinking, and my second aim is to explore how this definition can apply to religious education in The Church of Jesus Christ of Latter-day Saints.

\section{Defining Critical Thinking}

The first definition under consideration comes from a frequently cited website within the domain of critical thinking. Here critical theorists Michael Scriven and Richard Paul endeavor to encapsulate in one definition the wide expanse of critical thinking's many definitions: "Critical thinking is the intellectually disciplined process of actively and skillfully conceptualizing, applying, analyzing, synthesizing, and/or evaluating information gathered from, or generated by, observation, experience, reflection, reasoning, or communication, as a guide to belief and action. In its exemplary form, it is based on universal intellectual values that transcend subject matter divisions: clarity, accuracy, precision, consistency, relevance, sound evidence, good reasons, depth, breadth, and fairness." ${ }^{6}$

Assessing the definition in parts will allow for a thorough examination, beginning with a look at critical thinking as being active and intellectually disciplined. Such admonitions are repeated often in the scriptures. The thirteenth article of faith teaches that members of the Church "seek after" anything that is "virtuous, lovely, or of good report or praiseworthy." The Prophet Joseph Smith borrows terminology here from what he calls the "admonition of Paul" - from the book of Philippians, where Paul lists many of the same qualities and then suggests, "Think on these things" (Philippians $4: 8)$.

Common scriptural words that suggest active, skillful, and disciplined thinking include inquiring, pondering, reasoning, and asking. Additional scriptures suggest such things as "study it out in your mind" (D\&C 9:8) or "seek learning, even by study and also by faith" (D\&C 88: I I 8). Assuredly, the portion of the definition of critical thinking pertaining to intellectual discipline fits well within the objectives of the Church's education program.

The next part of the definition given by Scriven and Paul includes "conceptualizing, applying, analyzing, synthesizing, and/or evaluating information." The Gospel Teaching and Learning handbook, used by teachers and leaders in the Seminaries and Institutes of Religion program of the Church, sets forth the "fundamentals of gospel teaching and learning." Included in these fundamentals are (a) identifying doctrines and principles, (b) understanding the meaning of those doctrines and principles, (c) feeling the truth and importance of those doctrines and principles, and (d) applying doctrines and principles. Comparing the definition for critical thinking to the fundamentals of gospel teaching and learning, one can argue that conceptualizing is akin to identifying and analyzing, both of which require the understanding sought for by the previously mentioned fundamentals. Synthesizing and evaluating can be a part of understanding and feeling the importance of a concept. Also, application is found in both the definition and the fundamentals of gospel teaching and learning. It is an integral part of critical thinking and effective religious education within the Church.

Finally, according to this definition, critical thinking assesses "information gathered from, or generated by, observation, experience, reflection, reasoning, or communication, as a guide to belief and action." This portion of the definition seems equally suited for religious education. So much of religion is based on personal experience and reflection on those experiences. Owing to the personal nature of religious observations, experiences, reflections, and reasoning, adherents often find them difficult to fully explain. This personal experience may be compared to a baseball player who has mastered the art of batting. Intellectually, the player may understand perfectly what must be done, as he or she may have practiced it innumerable times, but when 
asked to explain it to someone else the player is unable to do so. Such a situation does not detract from the fact that the batter has mastered the art, yet the explanation remains difficult. Additionally, religious experiences are often very personal in nature. Due to the value attributed to those experiences, a person may not choose to share them frequently because of a fear that others will not understand or may even attempt to degrade and minimize those experiences and the feelings associated with them. Thus, even on the occasion when someone attempts to articulate such experiences, they remain unexplained.

In a religious setting, information derived from observation, experience, and communication may come from meeting with others who share religious beliefs. Moroni 6:5 touches on this idea. "And the church [members] did meet together oft, to fast and to pray, and to speak with one another concerning the welfare of their souls." Congregating has long been a cornerstone of religious experience. Doing so provides members opportunities for observation, experience, reflection, and communication, all of which make up the delicate tapestry of religious belief and behavior.

Adding to the definition given by Scriven and Paul, college professor and author Tim John Moore asserts that another quality important in critical thought is skepticism, verging on agnosticism, toward knowledge—calling into question whether reality can be known for certain. ${ }^{8}$ This skepticism carries with it immediate doubt prior to being presented with knowledge. Others have termed it as a "doubtful mentality." This definition does not seem able to coexist with faith-motivated critical thinking. Many scriptures teach about the importance of faith trumping doubt, the most recognizable among them likely being James I: 5-6: "If any of you lack wisdom, let him ask of God, that giveth to all men liberally, and upbraideth not; and it shall be given him. But let him ask in faith, nothing wavering. For he that wavereth is like a wave of the sea driven with the wind and tossed."

Concerning the type of doubt that arises even before learning facts, Dieter F. Uchtdorf of the Church's First Presidency said, "Doubt your doubts before you doubt your faith." ${ }^{10}$ This admonition indicates that there is an ultimate source of truth, and when our doubts loom large it is better to doubt those doubts instead of doubting God. The Doctrinal Mastery: Core Document, a part of the S\&I curriculum introduced in the summer of 2016 , states that "God ... is the source of all truth. ... He has not yet revealed all truth." Thus, doubt should be curbed at the point when we do not have all the evidence or answers we seek. Such is the case in the scientific method: a tested hypothesis leads to a theory, and confirmed theories lead to laws. Fortunately, neither hypotheses nor theories are abandoned for lack of proof or the existence of doubt concerning them.

Some within a religious community may be hesitant to apply critical thinking to their own religious beliefs, believing that doing so could weaken their faith. Psychologist Diane Halpern, however, suggests that critical thinking need not carry with it such negative connotations. "In critical thinking, the word critical is not meant to imply 'finding fault,' as it might be used in a pejorative way to describe someone who is always making negative comments. It is used instead in the sense of 'critical' that involves evaluation or judgement, ideally with the goal of providing useful and accurate feedback that serves to improve the thinking process." ${ }^{12}$ Applying critical thinking need not indicate a lack of faith by a believer-an important point to consider when applying critical thinking to religious education. Critically thinking Christian believers are adhering to the Savior's commandment to "ask, and it shall be given you; seek, and ye shall find; knock, and it shall be opened unto you" (Matthew 7:7).

Religious believers may be concerned that other critical thinkers have reached an opinion different than theirs. This concern can be addressed by the way critical thinking is defined. Professor of philosophy Jennifer Mulnix writes that "critical thinking, as an intellectual virtue, is not directed at any specific moral ends." ${ }^{13}$ She further explains that critical thinkers do not have a set of beliefs that invariably lead to specific ends, suggesting that two critical thinkers who correctly apply the skills and attitudes of critical thinking to the same subject could hold opposing beliefs. Such critical thinking requires a sort of mental flexibility, a willingness to acknowledge that a person may not be in possession of all the facts. Including such flexibility when defining critical thinking does not disqualify its application to religious education. A religious person can hold beliefs and knowledge while remaining flexible, just as a mathematician holds firm beliefs and knowledge but is willing to accept more and consider alternatives in the light of additional information. In other words, being in possession of facts that a person is unwilling to relinquish does not mean that he or she is unwilling to accept additional facts.

Elder Dallin H. Oaks spoke about the idea of differing conclusions when addressing religious educators. "Because of our knowledge of [the] Plan and other truths that God has revealed, we start with different assumptions than 
those who do not share our knowledge. As a result, we reach different conclusions on many important subjects that others judge only in terms of their opinions about mortal life." ${ }^{14}$ Each person brings different life experience and knowledge, which they call upon to engage in critical thinking. While both are employing critical-thinking skills, they may be doing so with different facts and differing amounts of facts. All of the facts in consideration may be true, but because of the way those facts are understood, different conclusions are reached. Still, the thinking taking place can be correctly defined as critical.

Another belief included by some in a definition of critical thinking, though at odds with the edifying instruction presented in LDS religious education, is addressed by Rajeswari Mohan, who suggests that to teach using critical thinking would require "a re-understanding of the classroom."15 Generally, the understanding that currently exists of the classroom, both inside and outside of religious education, consists of creating an atmosphere of respect and trust, a safe place to learn and grow-something that Mohan calls "cosmopolitan instruction." ${ }^{16}$ In its place Mohan advocates that the classroom become "a site of contestation," 17 which connotes controversy, argument, and divisiveness. Of course, it is possible to contest a belief, debate, and even disagree while still maintaining trust and respect, but such a teaching atmosphere is what Mohan considers cosmopolitan and, as such, it would require no re-understanding to accomplish it.

Elizabeth Ellsworth described her experience when attempting to employ the type of approach Mohan suggests in her own classroom. ${ }^{18}$ In reflecting on the experience, she noted that it exacerbated disagreements between students rather than resolving or solving anything. She summarized what took place by saying, "Rational argument has operated in ways that set up as its opposite an irrational Other." ${ }^{19}$ Rather than having her class engage in discussion and learning, Ellsworth witnessed students who refused to talk because of the fear of retaliation or fear of embarrassment.

Such a situation does not align with D\&C 42: 4 , "If ye receive not the Spirit ye shall not teach." Additionally, this confrontational atmosphere in the learning environment seems to run counter to the doctrines taught by the Savior. Consider the words of Christ in 3 Nephi i I:29: "I say unto you, he that hath the spirit of contention is not of me, but is of the devil, who is the father of contention, and he stirreth up the hearts of men to contend with anger, one with another."
Many authors who offer definitions of critical thinking discuss how critical thinking leads to action; one author states, "Criticality requires that one be moved to do something." ${ }^{20}$ President Thomas S. Monson, while a member of the Quorum of the Twelve Apostles, said, "The goal of gospel teaching... is not to 'pour information' into the minds of class members. ... The aim is to inspire the individual to think about, feel about, and then do something about living gospel principles." 21 This application is the foundation of the teachings of Jesus Christ, the very purpose of his Atonement, to allow for individuals to change. This change does not solely consist of stopping some behavior but also includes starting new behaviors. Elder Neal A. Maxwell, for example, suggested that many of us could make more spiritual progress "in the realm of the sins of omission ... than in any other place."22

\section{Critical Thinking Exaggerated}

President Boyd K. Packer taught that "tolerance is a virtue, but like all virtues, when exaggerated, it transforms itself into a vice." ${ }^{23}$ This facet of critical thinking whereby critical thinking prompts action must be explained carefully, as it can be exaggerated and transformed into a vice. Mohan described this aspect of critical thinking that moves individuals to action outside of the classroom as having a "goal of transformative political action" aimed at challenging, interrupting, and undercutting "regimes of knowledge." ${ }^{4}$ Pedagogy of the Oppressed author and political activist Paulo Freire taught that this action brought about the "conquest" 25 of an oppressed class in a society over its oppressors. Some would argue that if it does not lead to this kind of contending, transformative action, critical thinking is incomplete. ${ }^{26}$

Transformative action taken by individuals to change themselves is necessary. Yet the idea that one can effect change within the Church, for individuals or the organization itself, by compulsion or coercion in a spirit of conquest can lead to "the heavens [withdrawing] themselves; the Spirit of the Lord [being] grieved" (D\&C I I:37). Critical thinking defined to include this contention does not have a place in religious education within the Church.

A balanced definition of critical thinking that allows for faith in things which are hoped for and yet unseen (see Alma 32:2 I) may look something like this: Critical thinking consists of persistent, effortful, ponderous, and reflective thought devoted to concepts held and introduced through various ways, including experience, inquiry, and reflection. That person then analyzes, evaluates, and attempts to understand how those concepts coincide 
and interact with existing knowledge, ready to abandon or employ ideas based upon their truthfulness. This contemplation then leads the person to consistent and appropriate actions.

Because of the benefits of critical thinking, some have taken its application to an extreme, allowing it to undermine faith. Addressing a group of college students in 1996, President Gordon B. Hinckley said, "This is such a marvelous season of your lives. It is a time not only of positive thinking but sometimes of critical thinking. Let me urge you to not let your critical thinking override your faith., ${ }^{27}$

\section{Examples in Doctrine}

Despite a potential to undermine faith when applied incorrectly, critical thinking holds too much promise to be abandoned. This is particularly the case for religious education in The Church of Jesus Christ of Latter-day Saints. Not only do questions and critical thought have an appropriate place in the Church, but as President Dieter F. Uchtdorf has pointed out, the Church would not exist without it. ${ }^{28} \mathrm{He}$ explains that the doctrinally loaded and foundational experience of the First Vision came as the result of Joseph Smith's critical thought toward existing churches and a desire to know which he should join. Knowing for ourselves if the church that was restored through Joseph Smith's efforts is truly the "only true and living church" (D\&C $\mathrm{I}: 30)$ can be done only by following his lead and "ask[ing] of God" (James I:5). "Asking questions," President Uchtdorf said, "isn't a sign of weakness; it's a precursor of growth." ${ }^{29}$

This concept of critically thinking while still acting in faith is illustrated in Alma 32:27-43, when Alma teaches a group of nonbelievers who nonetheless want to know the truth. Table I compares Alma's words with concepts of critical thinking.

\begin{tabular}{|c|c|c|}
\hline Verse & Scriptural Phrase & Critical-Thinking Counterpart \\
\hline 27 & Awake and arouse your faculties & Effortful thinking \\
\hline 27 & Experiment upon my words & $\begin{array}{l}\text { Analyze, evaluate, attempt to } \\
\text { understand }\end{array}$ \\
\hline 28 & Give place for & $\begin{array}{l}\text { Understand how concepts coincide and } \\
\text { interact with existing knowledge }\end{array}$ \\
\hline 28 & Do not cast it out by your unbelief & Ready to abandon or employ any idea \\
\hline
\end{tabular}

\begin{tabular}{|c|c|c|}
\hline 28,34 & $\begin{array}{l}\text { Swelling motions, enlarge my soul, } \\
\text { enlighten my understanding, mind } \\
\text { doth begin to expand }\end{array}$ & $\begin{array}{l}\text { "Enhances rationality," }{ }^{30} \text { "serves to } \\
\text { improve the thinking process" }\end{array}$ \\
\hline 34 & Your knowledge is perfect in that thing & $\begin{array}{l}\text { Employ any idea depending on its } \\
\text { truthfulness }\end{array}$ \\
\hline 36 & Neither must ye lay aside your faith & Persistent \\
\hline $37-38$ & Nourish it & $\begin{array}{l}\text { Persistent, interact with existing } \\
\text { knowledge }\end{array}$ \\
\hline $41-42$ & Diligence, patience & Persistent, ponderous \\
\hline
\end{tabular}

Figure 1. Alma and Critical Thinking.

The necessity of exercising faith is a major component of all religion. "For my thoughts are not your thoughts, neither are your ways my ways, saith the Lord. For as the heavens are higher than the earth, so are my ways higher than your ways, and my thoughts than your thoughts" (Isaiah 55:8-9). "Now faith is the substance of things hoped for, the evidence of things not seen" (Hebrews I I:I). "I was led by the Spirit, not knowing beforehand the things which I should do" (I Nephi 4:6). "Look unto me in every thought; doubt not, fear not" (D\&C 6:36). The skeptical critic of religion could assert that these statements amount to blind faith or towing the line without a rational or logical reason to do so. Applying critical thinking to such assertions may disclose, ironically, that such approaches are no different than using rational thought.

In Educating Reason, author Harvey Siegel responds to a criticism sometimes waged against critical thinking called the indoctrination objection. His argument provides a means for reconciling faith with logic. In short he observed that critical thinkers have traditionally been opposed to indoctrination of any kind. Over time much has been applied to the perception of, and even the definition of, indoctrination, which now carries with it highly negative connotations of teaching content that is either not true or is taught in such a way that the learner is not provided a way to measure the truthfulness of what is being taught. Yet the fundamental definition of indoctrination is simply to teach.

The indoctrination objection is based on the idea that critical thinkers want to reject all indoctrination, but they cannot do so because critical thinking itself must be taught (indoctrinated). The definition he gives to indoctrination is when students "are led to hold beliefs in such a way that they 
are prevented from critically inquiring into their legitimacy and the power of the evidence offered in their support; if they hold beliefs in such a way that the beliefs are not open to rational evaluation or assessment." ${ }^{32}$ Siegel delicately defines an indoctrinated belief as "a belief [that] is held non-evidentially." 33

It must be acknowledged that children are not born valuing rational thought and evidence; those values must be taught, or indoctrinated. According to Siegel, "If an educational process enhances rationality, on this view, that process is justified." ${ }^{4} \mathrm{He}$ later adds that such teaching is not only defensible, but necessary. "We are agreed that such belief-inculcation is desirable and justifiable, and that some of it might have the effect of enhancing the child's rationality. Should we call it indoctrination? This seems partly, at least, a verbal quibble." ${ }^{35}$

A teacher is justified in teaching students and a learner is justified in studying if doing so will eventually enhance rationality and if students are allowed to evaluate for themselves what is being taught.

There may even be a period when rationality is put on hold, or the lack of rationality perpetuated, temporarily for the sake of increasing critical thought in the end. This concept of proceeding with learning without first having an established rationale for doing so is the very concept of faith. Just as "faith is not to have a perfect knowledge of things" (Alma 32:2 I), reasons may not always be understood at first, just as a rational understanding for accepting a teaching is not always given at first. The moment when a learner must accept a teaching without first having a sufficient reason for doing so is faith. Students who continue to engage in the learning process are acting in faith. If the things being taught are true, those things will eventually lead those students to increased rationality and expanded intellect. Such teaching should not detour the student from seeking his or her own personal confirmation. Teaching in a manner that discourages students from establishing their own roots deep into the ground is antithetical to both critical thinking and the purposes of LDS religious education.

Teaching in a way that encourages and invites students to think critically about doctrines reflects not only teaching practices encouraged in today's religious education within the Church but also doctrines of the Church. The culture and doctrine of the Church seeks to avoid indoctrinating members in the negative or pejorative sense. On the Church's official Newsroom website is an article explaining what constitutes the doctrines of the Church. Included in that list is this statement: "Individual members are encouraged to independently strive to receive their own spiritual confirmation of the truthfulness of Church doctrine. Moreover, the Church exhorts all people to approach the gospel not only intellectually but with the intellect and the spirit, a process in which reason and faith work together." ${ }^{36}$ More than solely a statement of doctrine on a newsroom website, this concept is bolstered by the words of canonized scripture: "Seek learning, even by study and also by faith" (D\&C 88: I 1 8). "You have not understood; you have supposed that I would give it unto you, when you took no thought save it was to ask me. But you must study it out in your mind; then you must ask me" (D\&C 9:7-8). And finally, from the admonition of Paul, who, after speaking of doctrines, counseled believers to "think on these things" (Philippians 4:8).

The Prophet Joseph Smith addressed the relationship between faith and intellect. "We consider," he said, "that God has created man with a mind capable of instruction, and a faculty which may be enlarged in proportion to the heed and diligence given to the light communicated from heaven to the intellect; and that the nearer man approaches perfection, the clearer are his views." ${ }^{37}$ In other words, acting in faith, or giving heed and diligence to light communicated from heaven, can enlarge the intellectual faculty and clarify views. Diligence and heed are required in religious education, in which the content being taught is considered irrational by secular society. Amid ridicule by the irreligious, when the intellect is enlarged, the faithful recognize enhanced rationality and clearer views that are never realized by those who are ridiculing. This process continues until full rationality is achieved and the promise of God is fulfilled: "Nothing is secret, that shall not be made manifest; neither any thing hid, that shall not be known" (Luke 8:17). What a promise for a critical thinker!

\section{Conclusion}

Critical thinking has the potential to be a powerful tool for educators; that potential does not exclude its use by teachers within the Church. When used appropriately, critical thinking can help students more deeply understand and rely upon the teachings and Atonement of Jesus Christ. The testimony that comes as a result of critical thought can carry students through difficult times and serve as an anchor through crises of faith. As Elder M. Russell Ballard teaches,

Gone are the days when a student asked an honest question and a teacher responded, "Don't worry about it!" Gone are the days when a student raised a sincere concern 
and a teacher bore his or her testimony as a response intended to avoid the issue. Gone are the days when students were protected from people who attacked the Church. Fortunately, the Lord provided this timely and timeless counsel to you teachers: "And as all have not faith, seek ye diligently and teach one another words of wisdom; yea, seek ye out of the best books words of wisdom; seek learning, even by study and also by faith." ${ }^{38}$

Critical thought does not consist of setting aside faith, but rather faith is using critical thought to come to know truth for oneself.

\section{Notes}

I. Andrew Davis, "Defending Religious Pluralism for Religious Education," Ethics and Education 3, no. 5 (November 2010): 190.

2. Oduntan Jawoniyi, "Religious Education, Critical Thinking, Rational Autonomy, and the Child's Right to an Open Future," Religion and Education 39, no. I (January 20 I 5 ): 34-53; and Michael D. Waggoner, "Religion, Education, and Critical Thinking," Religion and Education 39, no. 3 (September 2012): 233-34

3. Waggoner, "Religion, Education, and Critical Thinking," 233-34.

4. Duck-Joo Kwak, "Re-Conceptualizing Critical Thinking for Moral Education in Culturally Plural Societies," Educational Philosophy and Theory 39, no. 4 (August 2007): 464.

5. Jawoniyi, "Religious Education," 46.

6. Michael Scriven and Richard Paul, quoted in "Defining Critical Thinking,"

Foundation for Critical Thinking, http://www.criticalthinking.org/pages /defining-critical-thinking/ 766 .

7. Gospel Teaching and Learning Handbook: A Handbook for Teachers and Leaders in

Seminaries and Institutes of Religion (Salt Lake City: The Church of Jesus Christ of Latter-day Saints, 20I 2), 39 .

8. Tim John Moore, "Critical Thinking and Disciplinary Thinking: A Continuing

Debate," Higher Education Research \& Development 30, no. 3 (June 20 I I ): 26 I-74.

9. Ali Mohammad Siahi Atabaki, Narges Keshtiaray, Mohammad Yarmohammadian,

"Scrutiny of Critical Thinking Concept," International Education Studies 8, no. 3 (February 2015): 100.

Io. Dieter F. Uchtdorf, "The Reflection in the Water" (CES fireside for young adults at Brigham Young University, I November 2009), https://www.lds.org/media-library

/video/2009-I I-0050-the-reflection-in-the-water?lang=eng\#d.

I I. Seminaries and Institutes of Religion, Doctrinal Mastery: Core Document (Salt Lake

City: The Church of Jesus Christ of Latter-day Saints, 20 16), 2

I 2. Diane F. Halpern, "Teaching Critical Thinking for Transfer across Domains," The American Psychologist 53, no. 4 (April I 998): 45 I.

I3. Jennifer Wilson Mulnix, "Thinking Critically About Critical Thinking," Educational Philosophy and Theory 44, no. 5 (July 20 I 2): 466.

I 4. Dallin H. Oaks, "As He Thinketh in His Heart" (evening with a General Authority 8 February 2013), https://www.lds.org/prophets-and-apostles/unto-all-the-world /as-he-thinketh-in-his-heart-?lang=eng.

I s. Rajeswari Mohan, "Dodging the Crossfire: Questions for Postcolonial Pedagogy,"

College Literature 19/20, vol. 3/1 (October 1992-February 1993): 30.
16. Mohan, "Dodging the Crossfire," 30.

17. Mohan, "Dodging the Crossfire," 30.

I 8. Elizabeth Ellsworth, "Why Doesn't This Feel Empowering? Working through the Repressive Myths of Critical Pedagogy," Harvard Educational Review 59, no. 3 (September 1989): 297-325.

19. Ellsworth, "Why Doesn't This Feel Empowering?," 30 I.

20. Nicholas C. Burbules and Rupert Berk, "Critical Thinking and Critical Pedagogy: Relations, Differences, and Limits," in Critical Theories in Education, ed. Thomas S.

Popkewitz and Lynn Fendler (New York: Routledge, i 999), 45-66.

21. Thomas S. Monson, in Conference Report, October 1970, 107.

22. Neal A. Maxwell, “The Precious Promise," Ensign, April 2004, 45, https://www.lds org/ensign/2004/04/the-precious-promise?lang=eng.

23. Boyd K. Packer, “These Things I Know," Ensign, May 2013, 8, https://www.lds.org /ensign/2013/05/these-things-i-know ?lang=eng.

24. Mohan, "Dodging the Crossfire," 30.

25. Paulo Freire, Pedagogy of the Oppressed, trans. Myra Bergman Ramos (New York: Continuum International, I 970).

26. Donaldo Macedo, introduction to Freire, Pedagogy of the Oppressed, i I-26.

27. Gordon B. Hinckley, "Excerpts from Recent Addresses of President Gordon B.

Hinckley," Ensign, October 1996, https://www.lds.org/ensign/1996/ 10

/excerpts-from-recent-addresses-of-president-gordon-b-hinckley?lang=eng.

28. Uchtdorf, "The Reflection in the Water."

29. Uchtdorf, "The Reflection in the Water."

30. Harvey Siegel, "Indoctrination Objection," in Educating Reason: Rationality,

Critical Thinking, and Education (New York: Routledge, I 988), 78-90.

3 r. Halpern, "Teaching Critical Thinking for Transfer across Domains," 45 I.

32. Siegel, Educating Reason, 80.

33. Siegel, Educating Reason, 8 o.

4. Siegel, Educating Reason, 81

35. Siegel, Educating Reason, 82.

36. "Approaching Mormon Doctrine," 4 May 2007, http://www.mormonnewsroom org/article/approaching-mormon-doctrine.

37. B. H. Roberts, A Comprehensive History of the Church of Jesus Christ of Latter-day Saints, 2nd ed. (Salt Lake City: Deseret Book, 1976), 2:8.

38. M. Russell Ballard, "The Opportunities and Responsibilities of CES Teachers in the 2 ist Century" (address to CES religious educators, 26 February 2016), https://www.lds.org/ broadcasts/article/evening-with-a-general-authority/2016/02/the-opportunities-and -responsibilities-of-ces-teachers-in-the-2 I st-century?lang=eng\&_ $r=\mathrm{I}$. 